\title{
Assessment of progesterone profiles and postpartum onset of luteal activity in spring calving Hereford beef suckler cattle
}

\author{
Adam D Martin*1, Marit L Lystad², Olav Reksen¹, Erik Ropstad', Andres Waldmann³, Ola Nafstad² and Knut Karlberg
}

\begin{abstract}
Background: Reproduction is the single greatest factor limiting beef cattle production. Previous research on beef suckler luteal activity has largely focused on the mechanisms, and duration, of postpartum anoestrus. However, the temporal pattern of luteal activity after resumption of post-partum ovarian activity, and the impact of pattern type on days open (DO) in purebred beef suckler cows, are unknown.

Methods: Progesterone concentration was measured in milk samples taken thrice weekly from 120 lactations, in 87 animals, on 3 farms, over two years. Onset of luteal activity (OLA) was defined as the first day milk progesterone concentration exceeded $3 \mathrm{ng} / \mathrm{ml}$ for two successive measurements, or exceeded $5 \mathrm{ng} / \mathrm{ml}$ once. It was defined as delayed if it occurred more than 61 days postpartum. A short initial luteal phase consisted of progesterone concentrations which exceeded $3 \mathrm{ng} / \mathrm{ml}$ for fewer than 4 sequential measurements. Temporal progesterone patterns were classified as: 1) Normal cyclicity; 2) Cessation of luteal activity; 3) Prolonged luteal activity; 4) Erratic phase: failure to conform to 1,2 or 3. Data concerning parity, previous calving interval, breeding values, calf birth and 200-d weight were obtained from the Norwegian Beef Cattle Recording System database.

Results: The mean (SD) OLA was 41 d (20). Parity and calf birth weight were inversely correlated with OLA. Delayed OLA occurred in $14.4 \%$ of lactations. A short first luteal phase occurred in $61.5 \%$ of lactations, but this was unrelated to irregular luteal phase occurrence, pregnancy or DO. Irregular luteal phases occurred in $22 \%$ of lactations. The irregularities were: prolonged luteal phase (11\%); cessation of luteal activity (5\%); erratic luteal activity (6\%). Early OLA was associated with prolonged luteal phases. DO was positively correlated with irregular luteal phases and negatively correlated with calf 200-d weight.

Conclusions: This study demonstrates that irregular luteal phases negatively affect reproductive performance in purebred beef suckler cattle. A moderate incidence of irregular luteal phases was seen in the study population. Whilst a positive relationship was seen between OLA and DO, unfavourable associations between early OLA and incidence of irregular luteal phases should be considered when developing breeding programmes.
\end{abstract}

\section{Background}

Efficiency of beef production is of critical importance as the global demand for meat increases [1]. Furthermore, policy decisions taken at a European level in recent decades have encouraged lower stocking densities and a reduction in the use of nitrogen based fertiliser [2-4]. In Norway suckled calf production systems are largely pasture based, and despite recent increases in beef suckler

* Correspondence: adam.martin@nvh.no

1 Department of Production Animal Clinical Sciences, Norwegian School of Veterinary Science, Oslo, Norway

Full list of author information is available at the end of the article cow numbers, the country is not self sufficient in beef production, with a net import of 10,700 tonnes of beef and beef products in 2008 [5]. It is, therefore, important to identify and understand the bottlenecks present in the production system if action is to be taken to improve production efficiency.

The greatest factor limiting suckled calf production efficiency is suboptimal reproductive performance [6,7]. The duration of postpartum anoestrus largely determines the probability of females becoming pregnant during the breeding season [7]. Considerable attention has been paid 
to the pattern of reproductive cyclicity in the dairy population, how it has changed with time, and the negative impacts of irregular luteal phases on reproductive performance [8-11]. Additional studies describe the risk factors for ovarian dysfunction in high yielding dairy cows $[12,13]$. The heritability of onset of luteal activity (OLA) is relatively high when compared with the heritability of traditional measures of fertility [14] and, to an increasing extent, its use in breeding programmes to improve fertility has been advocated [15-17].

A number of studies have investigated the time to OLA in beef cows and the factors influencing it [18]. However, to the authors' knowledge no studies have characterised the temporal pattern of luteal activity after OLA, factors influencing the pattern of luteal activity, or the impact of pattern type on days open (DO) in purebred beef suckler cows. It is possible that, in an attempt to improve production efficiency, beef breeding programmes will increasingly emphasise fertility. Therefore, it is imperative that the temporal pattern of luteal activity is characterised, factors influencing it assessed, and consequences evaluated, as this information may prove fundamentally important in the development of future breeding programmes.

The objectives of the current study were, in purebred, pasture grazed, late winter/spring calving, Hereford suckler cows to: i) characterise the postpartum OLA and subsequent pattern of luteal activity; ii) study the relationship between individual cow/calf variables (parity, maternal breeding value, calf birth weight, calf gender, calf $200 \mathrm{~d}$ weight) and OLA, pattern of luteal activity and DO.

\section{Methods}

\section{Animals}

The study was undertaken over a period of two years and included 120 lactations (26 first, 20 second, and 74 third or later lactations ) from 87 purebred Hereford cattle. In the first year, two farms were included in the study (Farm A, $n=28$ animals and Farm B, $n=23$ animals), a third farm (Farm C) was recruited in the second year (Farm A, $\mathrm{n}=33$ animals, Farm B, $\mathrm{n}=18$ animals and Farm $\mathrm{C}, \mathrm{n}=$ 18 animals). No animals moved between the farms during the study. The three spring-calving commercial farms were all members of the Norwegian Beef Cattle Recording System (NBCRS) and volunteered to participate in the study. The reproductive management and feeding practices were similar on all three farms; concentrates, minerals and round-bale grass silage were fed during winter. Minerals and round bale silage supplemented the permanent pasture diet during the grazing season. Animals were separated from the herd for parturition, and rejoined the herd within three days of calving. Throughout the study, bulls, which had passed a breeding soundness examination, were kept with each herd at a female:male ratio below 40:1. Consequently, females were exposed to a bull constantly from Day 3, or earlier, postpartum. Pregnancy diagnosis was performed by transrectal palpation of the uterus every 3 weeks to identify 6 to 9 week pregnancies. The study was performed within the guidelines of the Norwegian School of Veterinary Science's Ethical committee.

\section{Sampling and Assay of Milk Progesterone}

Milk samples were collected thrice weekly from ten days postpartum until pregnancy had been confirmed. Samples were frozen within one hour of collection and transported to the hormone laboratory at the Norwegian School of Veterinary Science. Progesterone concentrations were determined from whole milk by enzyme immunoassay [19], using the second antibody coating technique [20]. The inter-assay coefficients of variation for progesterone concentration in whole milk at progesterone concentrations of 1.5 and $19.7 \mathrm{ng} / \mathrm{ml}$ were 9.2 and $5.3 \%$, respectively. The intra-assay coefficient of variation progesterone concentration in whole milk was less than $10 \%$. The limit of sensitivity, using a $20 \mu \mathrm{l}$ sample, was less than $0.5 \mathrm{ng} / \mathrm{ml}$.

\section{Onset of Luteal Activity}

The day of OLA after calving was determined using milk progesterone concentration data. It was defined as the first day that milk progesterone concentrations were greater than $3 \mathrm{ng} / \mathrm{ml}$ for two successive measurements, or greater than $5 \mathrm{ng} / \mathrm{ml}$ once $[19,21]$. Onset of luteal activity was defined as normal if it occurred within one standard deviation of the study population mean; early if it occurred before this, and delayed if it occurred after this.

\section{Temporal Pattern of Progesterone Concentration}

The initial luteal phase was described as short if progesterone concentrations exceeding $3 \mathrm{ng} / \mathrm{ml}$ were maintained for fewer than 4 measurements. Animals that experienced a short first luteal phase had their temporal pattern of progesterone concentration classified without this first, short, cycle. The temporal patterns of progesterone concentration were classified using categories described by Mann et al. [22]:

1) Normal cyclicity: periods of progesterone concentration below $3 \mathrm{ng} / \mathrm{ml}$ for less than 1 week followed by progesterone concentrations exceeding $3 \mathrm{ng} / \mathrm{ml}$ for more than 2 weeks, or high levels of progesterone concentration (exceeding $3 \mathrm{ng} / \mathrm{ml}$ ) in association with confirmed pregnancy.

2) Cessation of luteal activity: progesterone concentration less than $3 \mathrm{ng} / \mathrm{ml}$ for more than 2 weeks following a period of luteal activity.

3) Prolonged luteal activity: progesterone concentration greater than $3 \mathrm{ng} / \mathrm{ml}$ for more than 3 weeks, in the absence of pregnancy. 
4) Erratic phase: failure to conform with 1, 2 or 3.

Lactations with normal cyclicity were regarded as having regular luteal phases, whilst those which were not classified as having normal cyclicity were regarded as having irregular luteal phases.

\section{Individual Cow-Calf Variables}

Data on parity, previous calving interval, breeding values, calf birth weight and calf 200-d weights were obtained from the NBCRS database. Days open (DO) was defined as the number of days from calving until the last milk sample with a progesterone concentration measurement below $3 \mathrm{ng} / \mathrm{ml}$ preceding confirmed pregnancy was taken. Maternal calf 200-d weight breeding values were calculated using a best linear unbiased prediction (BLUP) model by the Norwegian Beef Breeding Association http://www.tyr.no. Maternal calf 200-d weight breeding value and calf 200 - $d$ weight were both tested as continuous variables and categorised by their quartiles. Four cows gave birth to twins: their data were removed from the statistical analyses.

\section{Statistical Analyses}

The likelihood of luteal phase irregularities was assessed using the categories 'regular' and 'irregular', in separate analyses the likelihood of 'prolonged luteal activity' was compared with 'normal cyclicity'. Only significant results from the 'prolonged luteal activity' vs. 'normal cyclicity' analyses have been reported. The dichotomous outcome variables were tested against explanatory variables both univariately and in multivariable models using a general estimating equation (GEE) approach with the GENMOD procedure in SAS [23]. Animals were nested within herd, which was accounted for by entering farm as a fixed effect to all analyses. Overall statistical significance was assessed by the score statistics for type III GEE Analysis.

Onset of luteal activity, DO, and previous calving interval were transformed using their natural logarithm because of the non-normality of these data, and tested as continuous variables. Relationships between the continuous outcome variables; InOLA and lnDO; and the explanatory variables were tested both univariately and in multivariable models using Proc Mixed in SAS [24]. Measurements between lactations within farms were not independent; 'farm' was included as a random factor in the model. Overall statistical significance was assessed by the type III F-test.

The inclusion of two lactations from individual animals in this study was accounted for by using a first order autoregressive correlation structure in all models. In all analyses statistical significance was considered with a $P$ value below 0.05 . Explanatory variables with a $P$-value below 0.20 in the univariate analyses were simultaneously entered in a multivariable model together with the first order interaction between all variables. A backwards elimination procedure was employed and variables with a $P$-value below 0.10 were retained in the model. Confounding was assessed by comparing parameter estimates. If the estimates varied by more than 20\%, confounding was regarded as being present [25].

\section{Results}

In seven lactations accurate determination of OLA was not possible, and these lactations were omitted from the analyses. Consequently, accurate assessment of the time from calving until to OLA was possible in 113 lactations (25 first, 17 second, and 71 third or later lactations) in 87 individual cows. The mean interval from calving until OLA (SD) was $41 \mathrm{~d}(20)$. Thus normal OLA was defined as being between 21 and $61 \mathrm{~d}$. Early OLA was seen in ten lactations (9\%). Delayed OLA occurred in sixteen lactations (14\%).

Sufficient data were available to make an accurate assessment of the length of the first luteal phase in 108 out of 113 lactations (24 first, 17 second, and 67 third or later lactations). Once luteal activity had begun a short luteal phase occurred in 63 of 108 lactations (Farm A 32/ 57, Farm B18/36, Farm C 13/15). Short first luteal phases were seen more frequently on Farm $C$ than on Farms A and $\mathrm{B}$ combined $(P=0.02)$. The odds ratio for a short first luteal phase was predicted to be 0.74 and 4.83 in Farms B $(\mathrm{n}=36)$ and $\mathrm{C}(\mathrm{n}=15)$, respectively compared to Farm A $(\mathrm{n}=57)(P=0.02)$. No associations were seen between the presence of a short first luteal phase and likelihood of pregnancy $(P=0.42), \operatorname{lnDO}(P=0.14)$ or time from lnOLA to pregnancy $(P=0.77)$.

Univariate analyses of the relationships between InOLA and the explanatory variables can be seen in Table 1. Parity was inversely related to InOLA when assessed univariately $(P<0.01)$, and primiparous animals took longer to OLA than both second lactation and third or later lactation cows (47, 42 and 32 days respectively). An inverse univariate relationship ( $P=0.001)$ was observed between lnOLA and calf birth weight; the increase of calf birth weight by $1 \mathrm{~kg}$ (range 24 to $57 \mathrm{~kg}$ ) shortened lnOLA by 0.04 units (range 3.08 to 4.26). The model estimated OLA to be 40 days in a cow giving birth to a calf of $40 \mathrm{~kg}$ body weight; whereas time to OLA in a cow giving birth to a calf of $50 \mathrm{~kg}$ was predicted to be 28 days. Calf birth weights differed $(P<0.05)$ with calf gender: bull calves weighed on average $43 \mathrm{~kg}$ at birth $(\mathrm{n}=56)$ and heifer calves $41 \mathrm{~kg}(\mathrm{n}=51)$.

When multivariable relationships were assessed between InOLA and the explanatory variables parity and calf birth weight, only the latter remained significantly $(P$ $=0.02$ ) associated with InOLA. After correction for the effect of parity, the predicted decrease in lnOLA per $\mathrm{kg}$ increase in calf birth weight changed from 0.036 to 0.028 , 
Table 1: Univariate relationships between the natural logarithm of onset of luteal activity and study variables

\begin{tabular}{|c|c|c|c|c|c|c|}
\hline Variable & Group & $\mathbf{n}$ & $\beta$-value & S.E. & F-value & $P$-value \\
\hline Calf 200-d weight & & 85 & 0.001 & 0.002 & 0.09 & 0.77 \\
\hline \multirow[t]{4}{*}{ Calf 200-d weight } & $1^{\text {st }}$ quartile & 20 & 0.049 & 0.156 & 0.39 & 0.76 \\
\hline & $2^{\text {nd }}$ quartile & 24 & 0.148 & 0.143 & & \\
\hline & $3^{\text {rd }}$ quartile & 20 & 0.073 & 0.142 & & \\
\hline & $4^{\text {th }}$ quartile & 21 & 0.000 & 0.000 & & \\
\hline Calf birth weight & & 95 & -0.036 & 0.011 & 11.49 & 0.001 \\
\hline \multirow[t]{4}{*}{ Calf birth weight } & $1^{\text {st }}$ quartile & 21 & 0.337 & 0.132 & 3.80 & 0.01 \\
\hline & $2^{\text {nd }}$ quartile & 27 & 0.354 & 0.127 & & \\
\hline & $3^{\text {rd }}$ quartile & 21 & 0.050 & 0.118 & & \\
\hline & $4^{\text {th }}$ quartile & 24 & 0.000 & 0.000 & & \\
\hline \multirow[t]{2}{*}{ Calf gender } & Male & 53 & 0.057 & 0.084 & 0.46 & 0.49 \\
\hline & Female & 55 & 0.000 & 0.000 & & \\
\hline Natural logarithm of previous calving interval & & 85 & 0.098 & 0.387 & 0.06 & 0.80 \\
\hline Maternal breeding value & & 102 & 0.006 & 0.006 & 1.07 & 0.30 \\
\hline \multirow[t]{4}{*}{ Maternal breeding value } & $1^{\text {st }}$ quartile & 26 & -0.026 & 0.151 & 0.02 & 1.00 \\
\hline & $2^{\text {nd }}$ quartile & 31 & -0.023 & 0.145 & & \\
\hline & $3^{\text {rd }}$ quartile & 22 & -0.040 & 0.162 & & \\
\hline & $4^{\text {th }}$ quartile & 23 & 0.000 & 0.000 & & \\
\hline \multirow[t]{3}{*}{ Parity } & $1^{\text {st }}$ & 25 & 0.377 & 0.113 & 5.84 & $<0.01$ \\
\hline & $2^{\text {nd }}$ & 17 & 0.210 & 0.117 & & \\
\hline & $>2^{\text {nd }}$ & 70 & 0.000 & 0.000 & & \\
\hline
\end{tabular}

which indicates that parity and birth weight are confounding variables [25].

The temporal pattern of progesterone concentration could not be categorized in four lactations due to missing data. Thus the classification of luteal activity was performed in 116 lactations ( 26 first, 19 second, and 71 third or later lactations). Irregular luteal phases, i.e. lactations not classified as having normal cyclicity, occurred in 26 of $116(22.4 \%)$ lactations. The irregularities characterised were: prolonged luteal phase $(\mathrm{n}=13 ; 11.2 \%)$, cessation of luteal activity $(\mathrm{n}=6 ; 5.2 \%)$, and erratic phase $(\mathrm{n}=7$; $6.0 \%)$. The results of univariate analyses of the relationships between the explanatory variables and incidence of irregular luteal phases are given in Table 2. Irregular luteal phases tended to be related to both $\operatorname{lnOLA}(P=$ $0.06)$ and categorized calf birth weight $(P=0.06)$. However, when analysed in the multivariable model, only categorised calf birth weight remained after the application of the backwards elimination procedure, reducing the multivariable model to a univariate assessment.

When the likelihood of prolonged luteal phases was assessed separately, the odds ratio of a prolonged luteal phase occurring was 5.33 for each unit decrease in InOLA (range: 2.30 to 4.68$)(P<0.01)$. This indicates a strong likelihood of a prolonged luteal phase occurring in cows with early OLA.

In total eleven animals were not identified as becoming pregnant in either one of the annual breeding seasons. The mean (SD) DO in pregnant animals was $73 \mathrm{~d}$ (33) (n $=109)$. Pregnancy was established earlier than Day 40 in 16 (14.6\%) lactations, and later than Day 106 in 16 (14.6\%) lactations.

Table 3 displays the univariate analysis of $\ln \mathrm{DO}$ and the explanatory variables. Parity was negatively associated with $\ln \mathrm{DO}$; first parity animals were predicted to be pregnant on Day 80, second parity on Day 58, third or later parity on Day 64 postpartum. Luteal phase irregularities, both overall and as assessed solely for prolonged luteal phases, were positively related to an increased number of DO $(P<0.01)$. The model predicted a $25 \mathrm{~d}$ increase in DO in those animals experiencing irregular luteal phases. The time until OLA was positively associated with DO. Maternal 200-d calf weight breeding value and calf 200-d weight were negatively associated with DO.

When multivariable relationships were assessed between $\operatorname{lnDO}$ and the explanatory variables, the variables luteal phase pattern, InOLA, calf 200-d weight, calf birth weight categorised by its quartiles and parity 
Table 2: Univariate relationship between incidence of irregular luteal phases and study variables

\begin{tabular}{|c|c|c|c|c|c|c|c|}
\hline Variable & Group & $\mathbf{N}$ & $\beta$-value & SE & Odds ratio & Chi-square & $P$-value \\
\hline Calf 200-d weight & & 88 & 0.008 & 0.006 & 1.01 & 1.25 & 0.27 \\
\hline \multirow[t]{4}{*}{ Calf 200-d weight } & $1^{\text {st }}$ quartile & 22 & -0.646 & 0.643 & 0.52 & 1.75 & 0.63 \\
\hline & $2^{\text {nd }}$ quartile & 24 & 0.296 & 0.664 & 1.34 & & \\
\hline & $3^{\text {rd }}$ quartile & 20 & -0.131 & 0.787 & 0.88 & & \\
\hline & $4^{\text {th }}$ quartile & 22 & 0.000 & 0.000 & 1.00 & & \\
\hline Calf birth weight & & 98 & 0.069 & 0.063 & 1.07 & 1.35 & 0.25 \\
\hline \multirow[t]{4}{*}{ Calf birth weight } & $1^{\text {st }}$ quartile & 21 & -0.280 & 0.706 & 0.76 & 7.48 & 0.06 \\
\hline & $2^{\text {nd }}$ quartile & 29 & -1.983 & 0.948 & 0.14 & & \\
\hline & $3^{\text {rd }}$ quartile & 23 & 0.003 & 0.598 & 1.00 & & \\
\hline & $4^{\text {th }}$ quartile & 25 & 0.000 & 0.000 & 1.00 & & \\
\hline \multirow[t]{2}{*}{ Calf gender } & Male & 56 & 0.115 & 0.437 & 1.12 & 0.07 & 0.79 \\
\hline & Female & 56 & 0.000 & 0.000 & 1.00 & & \\
\hline Natural logarithm of onset of luteal activity & & 110 & -1.003 & 0.537 & 0.37 & 3.58 & 0.06 \\
\hline Natural logarithm of previous calving interval & & 89 & 2.220 & 2.697 & 0.11 & 0.77 & 0.38 \\
\hline Maternal breeding value & & 107 & 0.032 & 0.026 & 1.03 & 1.45 & 0.23 \\
\hline \multirow[t]{4}{*}{ Maternal breeding value } & $1^{\text {st }}$ quartile & 26 & -1.674 & 0.751 & 0.19 & 6.50 & 0.08 \\
\hline & $2^{\text {nd }}$ quartile & 33 & -0.001 & 0.550 & 1.00 & & \\
\hline & $3^{\text {rd }}$ quartile & 22 & -0.969 & 0.691 & 0.38 & & \\
\hline & $4^{\text {th }}$ quartile & 26 & 0.000 & 0.000 & 1.00 & & \\
\hline \multirow[t]{3}{*}{ Parity } & $1^{\text {st }}$ & 26 & -0.443 & 0.619 & 0.64 & 1.20 & 0.55 \\
\hline & $2^{\text {nd }}$ & 19 & 0.475 & 0.613 & 1.61 & & \\
\hline & $>2^{\text {nd }}$ & 71 & 0.000 & 0.000 & 1.00 & & \\
\hline
\end{tabular}

remained in the model after the backwards selection procedure had been employed (Table 4). Compared to second parity cows and third or later parity cows, the model predicted that primiparous animals would experience 24 more DO. Animals that experienced luteal phase irregularities took 26 days longer to become pregnant than animals with normal cyclical activity. After correction for the explanatory variables, which included luteal phase irregularities, the multivariable model indicated that $\ln \mathrm{DO}$ increased by 0.26 units per unit increase in $\operatorname{lnOLA}$.

\section{Discussion}

The time from calving to OLA was predictably longer in the study population than has been recorded in dairy cattle $[8-11,26,27]$. The time from calving to OLA in the present study falls in the middle of the range (29 to $67 \mathrm{~d}$ ) provided by the review of 23 studies on beef suckler animals between 1963 and 1999 [18]. The relationship between parity and time to OLA, with primiparous animals taking a longer time to OLA than pluriparous cows, is well established $[18,27,28]$. The proportion of beef suckler cows exhibiting delayed and early OLA in this study was similar to a study involving beef cross dairy animals and those involving dairy cows [8-11,22,27].

Onset of luteal activity was positively associated with DO in the present study. When analysed in a univariate model parity, but not InOLA, was related to DO. However, when analysed in a more sophisticated multivariable model both parity and $\operatorname{lnOLA}$, along with calf 200-d weight, were related to DO. This is probably because parity is closely related to InOLA. The parameter estimates for lnOLA changes by almost $25 \%$ between the univariate and multivariable models, indicating confounding between the variables [25]. Taken together, DO was positively related to OLA, when the effect of parity was accounted for.

In this study the majority (61\%) of ovarian activity began with a short luteal phase, which concurs with previous studies [29-31]. Progesterone concentrations postpartum can be raised by the luteinization of ovarian follicles, or more commonly, after ovulation, with formation of a corpus luteum [32]. Short luteal phases are known to occur with an increased frequency in anoestrous suckler cows after the weaning of their calves [33]. In our study the risk of short luteal phases was higher on 
Table 3: Univariate relationships between natural logarithm of days open and studied variables

\begin{tabular}{|c|c|c|c|c|c|c|}
\hline Variable & Group & $\mathbf{n}$ & $\beta$-value & SE & F-value & $P$-value \\
\hline Calf 200-d weight & & 81 & -0.003 & 0.001 & 5.49 & 0.02 \\
\hline \multirow[t]{4}{*}{ Calf 200-d weight } & $1^{\text {st }}$ quartile & 21 & 0.286 & 0.100 & 3.14 & 0.03 \\
\hline & $2^{\text {nd }}$ quartile & 22 & 0.151 & 0.099 & & \\
\hline & $3^{\text {rd }}$ quartile & 19 & 0.250 & 0.113 & & \\
\hline & $4^{\text {th }}$ quartile & 19 & 0.000 & 0.000 & & \\
\hline Calf birth weight & & 91 & -0.008 & 0.010 & 0.56 & 0.46 \\
\hline \multirow[t]{4}{*}{ Calf birth weight } & $1^{\text {st }}$ quartile & 20 & 0.034 & 0.129 & 1.83 & 0.15 \\
\hline & $2^{\text {nd }}$ quartile & 27 & -0.206 & 0.114 & & \\
\hline & $3^{\text {rd }}$ quartile & 23 & -0.070 & 0.125 & & \\
\hline & $4^{\text {th }}$ quartile & 21 & 0.000 & 0.000 & & \\
\hline \multirow[t]{2}{*}{ Calf gender } & Male & 51 & -0.005 & 0.080 & 0.00 & 0.95 \\
\hline & Female & 54 & 0.000 & 0.000 & & \\
\hline \multirow[t]{2}{*}{ Luteal phase pattern } & Normal & 84 & -0.342 & 0.085 & 16.34 & 0.001 \\
\hline & Irregular & 24 & 0.000 & 0.000 & & \\
\hline \multirow[t]{2}{*}{ Luteal phase pattern } & Other & 96 & -0.290 & 0.114 & 6.42 & 0.01 \\
\hline & Prolonged & 12 & 0.000 & 0.000 & & \\
\hline Natural logarithm of onset of luteal activity & & 103 & 0.162 & 0.081 & 3.96 & 0.05 \\
\hline Natural logarithm of previous calving interval & & 78 & -0.452 & 0.440 & 1.06 & 0.31 \\
\hline Maternal breeding value & & 100 & -0.009 & 0.004 & 5.09 & 0.02 \\
\hline \multirow[t]{4}{*}{ Maternal breeding value } & $1^{\text {st }}$ quartile & 24 & 0.267 & 0.096 & 3.10 & 0.03 \\
\hline & $2^{\text {nd }}$ quartile & 32 & 0.221 & 0.086 & & \\
\hline & $3^{\text {rd }}$ quartile & 21 & 0.188 & 0.091 & & \\
\hline & $4^{\text {th }}$ quartile & 23 & 0.000 & 0.000 & & \\
\hline \multirow[t]{3}{*}{ Parity } & $1^{\text {st }}$ & 23 & 0.231 & 0.095 & 3.82 & 0.03 \\
\hline & $2^{\text {nd }}$ & 19 & -0.101 & 0.106 & & \\
\hline & $>2^{\text {nd }}$ & 67 & 0.000 & 0.000 & & \\
\hline
\end{tabular}

one of the farms compared to the other two, indicating that factors other than suckling are involved in determining their frequency.

The importance of short luteal phases for normal luteal cyclicity and oestrus expression has been discussed $[31,34]$. Ciccioli et al. [31] found that no cow displayed normal oestrous behaviour before the first postpartum progesterone concentration rise, but all cows did after this transient increase. Whilst Looper et al. [34] found that $81 \%$ of luteal phases preceded by a short luteal phase were normal, compared to just $36 \%$ that were not. However, in the present study no association was seen between the presence, or absence, of a short luteal phase at OLA and the likelihood of pregnancy or DO, and pregnancy coincided with the first progesterone concentration rise in 11 animals (10\%). Consequently, short luteal phases were not a prerequisite of normal reproductive function for the beef cattle in this study.
In the present study, $22 \%$ of lactations were associated with irregular luteal phases, considerably higher than the $7 \%$ incidence previously reported in beef cross dairy animals by Mann et al. [22]. The occurrence of irregular luteal phases increased DO in this study; this agrees with previous studies on dairy cattle [8-10,27]. The incidence of irregular luteal phases excluding delayed OLA, reported in the present study is similar to modern dairy populations (between 13 and 44\%) $[8,10,11,27,35]$. The increased incidence of irregular luteal phases found in dairy cattle are believed to be the result of intensive selection and management to produce high milk yields $[8,10,27]$. However, the selection and management pressures applied to the Hereford breed have been, and are, very different to those experienced by dairy cattle. This indicates that a certain level of irregular luteal phases may be regarded as normal in beef cattle as well as in dairy cows. 
Table 4: Multiple relationships between natural logarithm of days open and explanatory variables

\begin{tabular}{|c|c|c|c|c|c|c|}
\hline Variable & Group & $\mathbf{n}$ & $\beta$-value & SE & F-value & $P$-value \\
\hline Calf 200-d weight & & 81 & -0.003 & 0.001 & 11.25 & 0.001 \\
\hline \multirow[t]{4}{*}{ Calf birth weight } & $1^{\text {st }}$ quartile & 21 & -0.356 & 0.127 & 4.25 & 0.01 \\
\hline & $2^{\text {nd }}$ quartile & 22 & -0.285 & 0.085 & & \\
\hline & $3^{\text {rd }}$ quartile & 19 & -0.224 & 0.100 & & \\
\hline & $4^{\text {th }}$ quartile & 19 & 0.000 & 0.000 & & \\
\hline \multirow[t]{2}{*}{ Luteal phase pattern } & Normal & 84 & -0.370 & 0.089 & 17.19 & $<0.001$ \\
\hline & Irregular & 24 & 0.000 & 0.000 & & \\
\hline Natural logarithm of onset of luteal activity & & 103 & 0.263 & 0.067 & 15.21 & $<0.001$ \\
\hline \multirow[t]{3}{*}{ Parity } & $1^{\text {st }}$ & 23 & 0.261 & 0.097 & 3.73 & 0.03 \\
\hline & $2^{\text {nd }}$ & 19 & 0.001 & 0.097 & & \\
\hline & $>2^{\text {nd }}$ & 67 & 0.000 & 0.000 & & \\
\hline
\end{tabular}

The incidence of prolonged luteal phases in this study was far greater than in a previous study of beef cross dairy animals, $11 \%$ compared to $3 \%$ [22]. Early OLA is a risk factor for the occurrence of prolonged luteal phases in dairy cows [10-12]. Onset of luteal activity generally occurs earlier in dairy cows than in beef cows [18]. Therefore, it is interesting that in this study early OLA, as defined for beef cows, was associated with an increased incidence of prolonged luteal phases despite a number of the known risk factors (high milk yields, intensive genetic selection for milk production and uterine disease) being absent.

A possible confounding factor in this study was the use of unrecorded natural service. Previous estimates for late embryonic/early fetal loss range between 3 and approximately $10 \%[9,22,36]$. Whilst the current study indicates an association between early OLA and prolonged luteal phases further research is necessary to quantify the relative impact of embryonic/early fetal loss on this finding. However, as natural service is predominant in the beef suckler systems [37] the practical significance of this finding remains important. The current study implies that there may be an optimum time to introduce fertile bulls to cows postpartum to maximise reproductive performance as embryonic/early fetal loss will also increase DO. Furthermore, as unfavourable associations exist between early OLA and incidence of irregular luteal phases mean that the inclusion of early OLA in breeding programmes should proceed cautiously, at least until the effects of early OLA on the pattern of luteal activity are better understood.

Heavier calves at birth, when analysed in the multivariable model, were associated with an increased number of DO. However, in multivariable model predicting lnOLA, which accounted for the effects of parity, higher calf birth weights per se were associated with an earlier OLA in the current study. Heavier calves are more likely to be associated with dystocia and postpartum uterine disease, both of which are known to delay OLA $[38,39]$. Dystocia did not occur in the study population allowing a positive association between fetal growth rate and OLA to be revealed. This relationship may have been masked in previous studies by the relationship between high birth weight and dystocia.

Interestingly, 200- $d$ calf weight breeding value and calf 200-d weight were negatively associated with DO. This is reverse to the findings in previous studies which show increasing milk yields to be associated with increased calf weaning weight, and a decrease in subcutaneous fat depth, indicating negative energy balance [40,41], which in turn may adversely affect reproductive performance [18]. However, reported correlations between milk yield and calf 200 -d weight vary considerably in previous studies (between 0 and 0.8) [42], and further work is needed to explain the observed relationship.

\section{Conclusion}

This study demonstrates a moderate incidence of irregular luteal phases in purebred beef suckler cattle compared to previous studies in dairy cattle. The occurrence of a short luteal phase immediately following OLA did not influence the likelihood of abnormal luteal phases, likelihood of pregnancy or DO under the study conditions. Generally OLA was positively associated with DO. However, unfavourable associations were seen between early OLA and incidence of irregular luteal phases. Irregular luteal phases were shown to negatively affect reproductive performance, as measured by DO. This relationship should be considered when developing future breeding programmes. 


\section{Authors' contributions}

AM prepared the manuscript. AM, ML, OR, ER, ON, and KK were involved in the planning of the study. ER coordinated the laboratory analysis. AW prepared and supplied the progesterone assay used. AM and OR decided upon and performed the statistical analysis. All authors have read and approved the manuscript.

\section{Acknowledgements}

The authors would like to acknowledge: the Foundation for Research Levy on Agricultural Products for funding the project; the farmers involved for their careful recordings and patient collection of milk samples; Ellen Dahl and Kjersti Finsrud for their assistance in analysing the samples; the late Kjell Andersen Berg for his contribution toward the collection of field data.

\section{Author Details}

'Department of Production Animal Clinical Sciences, Norwegian School of Veterinary Science, Oslo, Norway, ${ }^{2}$ Animalia - Meat and Poultry Research Centre, Oslo, Norway and 3 Institute of Veterinary Medicine and Animal Sciences, Estonian University of Life Sciences, Tartu, Estonia

Received: 3 December 2009 Accepted: 15 June 2010

Published: 15 June 2010

\section{References}

1. Food and Agricultural Organisation of the United Nations: FAO commodities and trade technical paper 1: Medium-term prospects for agricultural commodities; projections to the year 2010 Rome: Food and Agricultural Organisation of the United Nations; 2003

2. European Union: Council Regulation (EC) No. 2078/92. 1992

3. European Union: Council Regulation (EC) No.1094/88. 1988.

4. European Union: Council Regulation (EC) No. 1782/2003. 2003.

5. Animalia: Kjøttets Tilstand 2009; Annual Report of Norwegian Meat and Egg Production 20092009.

6. Dickerson G: Efficiency of animal production - molding biological components. J Anim Sci 1970, 30:849-859.

7. Short RE, Bellows RA, Staigmiller RB, Berardinelli JG, Custer EE: Physiological-mechanisms controlling anestrus and infertility in postpartum beef-cattle. J Anim Sci 1990, 68:799-816.

8. Opsomer G, Coyyn M, Deluyker H, de Kruif A: An analysis of ovarian dysfunction in high yielding dairy cows after calving based on progesterone profiles. Reprod Domest Anim 1998, 33:193-204.

9. Lamming GE, Darwash AO: The use of milk progesterone profiles to characterise components of subfertility in milked dairy cows. Anim Reprod Sci 1998, 52:175-190.

10. Royal MD, Darwash AO, Flint APE, Webb R, Woolliams JA, Lamming GE: Declining fertility in dairy cattle: changes in traditional and endocrine parameters of fertility. Animal Science 2000, 70:487-501.

11. Garmo RT, Martin AD, Thuen E, Havrevoll O, Steinshamn H, Prestløkken E, Randby A, Eknæs M, Waldmann A, Reksen O: Characterization of progesterone profiles in fall-calving Norwegian Red cows. J Dairy Sci 2009, 92:4919-4928

12. Opsomer G, Gröhn YT, Hertl J, Coyyn M, Deluyker H, de Kruif A: Risk factors for post partum ovarian dysfunction in high producing dairy cows in Belgium: a field study. Theriogenology 2000, 53:841-857.

13. Petersson KJ, Strandberg E, Gustafsson H, Berglund B: Environmental effects on progesterone profile measures of dairy cow fertility. Anim Reprod Sci 2006, 91:201-214.

14. Darwash AO, Lamming GE, Woolliams JA: Estimation of genetic variation in the interval from calving to postpartum ovulation of dairy cows. $J$ Dairy Sci 1997, 80:1227-1234.

15. Royal MD, Flint APF, Woolliams JA: Genetic and phenotypic relationships among endocrine and traditional fertility traits and production traits in Holstein-Friesian dairy cows. J Dairy Sci 2002, 85:958-967.

16. Petersson KJ, Berglund B, Strandberg E, Gustafsson H, Flint APF, Woolliams JA, Royal MD: Genetic analysis of postpartum measures of luteal activity in dairy cows. J Dairy Sci 2007, 90:427-434.

17. Veerkamp RF, Beerda B: Genetics and genomics to improve fertility in high producing dairy cows. Theriogenology 2007, 68:S266-S273.

18. Yavas $Y$, Walton JS: Postpartum acyclicity in suckled beef cows: a review. Theriogenology 2000, 54:25-55.

19. Waldmann A: Enzyme immunoassay (EIA) for milk progesterone using a monoclonal antibody. Anim/ Reprod Sci 1993, 34:19-30.
20. Waldmann A: Monoclonal antibodies to progesterone: Characterization and selection for enzyme immunoassay in bovine milk. Hybridoma 1999, 18:289-296

21. Matiko MK, Kanuya NL, Waldmann A, Ropstad E, Reksen O: Environmental constrains on post-partum ovarian activity in Tanzanian Zebu cows. Theriogenology 2008, 69:896-904.

22. Mann GE, Keatinge R, Hunter M, Hedley BA, Lamming GE: The use of milk progesterone to monitor reproductive function in beef suckler cows. Anim Reprod Sci 2005, 88:169-177.

23. Stokes ME, Davis CS, Koch GG: Categorical data analysis using the SAS system. 1995

24. Litell RC, Miliken GA, Stroup WW, Wolfinger RD: SAS system for mixed models. SAS Institute Inc.Cary, NC, USA; 1996.

25. Dohoo IR, Martin W, Stryhn H: Veterinary Epidemiological Research Charlottetown, Prince Edward Island: Transcontinental; 2003.

26. Darwash AO, Lamming GE, Woolliams JA: The potential for identifying heritable endocrine parameters associated with fertility in postpartum dairy cows. Animal Science 1999, 68:333-347.

27. Petersson KJ, Gustafsson H, Strandberg E, Berglund B: Atypical progesterone profiles and fertility in Swedish dairy cows. J Dairy SCi 2006, 89:2529-2538

28. Braden TD, King ME, Odde KG, Niswender GD: Development of preovulatory follicles expected to form short-lived corpora lutea in beef cows. J Reprod Fertil 1989, 85:97-104.

29. Werth LA, Whittier JC, Azzam SM, Deutscher GH, Kinder JE: Relationship between circulating progesterone and conception at the first postpartum estrus in young primiparous beef cows. J Anim Sci 1996, 74:616-619.

30. Humphrey WD, Kaltenbach CC, Dunn TG, Koritnik DR, Niswender GD: Characterization of hormonal patterns in the beef cow during postpartum anestrus. J Anim Sci 1983, 56:445-453.

31. Ciccioli NH, Wettemann RP, Spicer L, Lents CA, White FJ, Keisler DH: Influence of body condition at calving and postpartum nutrition on endocrine function and reproductive performance of primiparous beef cows. J Anim Sci 2003, 81:3107-3120.

32. Corah LR, Quealy AP, Dunn TG, Kaltenba CC: Prepartum and postpartum levels of progesterone and estradiol in beef heifers fed two levels of energy. J Anim Sci 1974, 39:380-385.

33. Odde KG, Ward HS, Kiracofe GH, McKee RM, Kittok RJ: Short estrous cycles and associated serum progesterone levels in beef cows. Theriogenology 1980, 14:105-112.

34. Looper ML, Lents CA, Wettemann RP: Body condition at parturition and postpartum weight changes do not influence the incidence of shortlived corpora lutea in postpartum beef cows. J Anim Sci 2003, 81:2390-2394

35. Shrestha HK, Nakao T, Suzuki T, Higaki T, Akita M: Effects of abnormal ovarian cycles during pre-service period postpartum on subsequent reproductive performance of high yielding Holstein cows. Theriogenology 2004, 61:1559-1571.

36. Ball PJB: The relationship of age and stage of gestation to the incidence of embryo death in dairy cattle. Res Vet Sci 1978, 25:120-122.

37. Vishwanath R: Artificial insemination: the state of the art. Theriogenology 2003, 59:571-584

38. Ducrot C, Gröhn YT, Humblot P, Bugnard F, Sulpice P, Gilbert RO: Postpartum anestrus in French beef-cattle - an epidemiologic-study. Theriogenology 1994, 42:753-764.

39. Holland MD, Odde KG: Factors affecting calf birth-weight - a review. Theriogenology 1992, 38:769-798.

40. Buckley F, O'Sullivan K, Mee JF, Evans RD, Dillon P: Relationships among milk yield, body condition, cow weight, and reproduction in springcalved Holstein-Friesians. J Dairy Sci 2003, 86:2308-2319.

41. Miller SP, Wilton JW, Pfeiffer WC: Effects of milk yield on biological efficiency and profit of beef production from birth to slaughter. Journal of Animal Science 1999, 77:344-352.

42. Fiems LO, Van Caelenbergh W, De Campeneere S, De Brabander DL: Effect of dam factors on milk intake and performance of Belgian Blue suckling calves. animal 2008, 2:135-140.

doi: 10.1186/1751-0147-52-42

Cite this article as: Martin et al., Assessment of progesterone profiles and postpartum onset of luteal activity in spring calving Hereford beef suckler cattle Acta Veterinaria Scandinavica 2010, 52:42 